\title{
A comparison of the orientation of joints with the focal mechanisms of earthquakes in the Alpine region
}

\author{
AdRIAN E. SCHEIDEgGer (*) \\ Received on July 4 th, 1977.
}

\begin{abstract}
It is well known that the principal tectonic stress directions in an area can be determined from earthquake fault plane solutions. Recently, a method has been developed by which these directions can also be determined from measurements of the orientation of joints in an area. In the present paper, a comparison is attempted between the directions calculated by the two methods for the Alpine region. It is shown that in Switzerland the agreement between the two methods is good.
\end{abstract}

Rinssunto - E noto che le principali direzioni dello stress tettonico in una data zona possono essere determinate dalle soluzioni del piano di faglia del terremoto. Recentemente è stato sviluppato un metodo in base al quale tali direzioni possono essere determinate misurando l'orientamento dei giunti in un'area. In questa nota viene tentato un confronto fra le direzioni calcolate con $\mathrm{i}$ due metodi per la regione Alpina. Viene mostrato che in Svizzera l'accordo fra i due metodi risulta soddisfacente.

\section{INTRODUCTION.}

It is well known that fault plane solutions of earthquakes permit one to make inferences regarding the stresses acting at the focus. Notably, the direction of the largest $(P)$ and smallest $(T)$ tectonic compression can be deduced.

If, in a region, one has a series of fault plane solutions of earthquakes, the resulting $P$ and $T$ dirctions can be averaged by a method developed by Fara and Scheidegger (1963) to yield the best fitting "seismic stress-directions» for the region in question. 
As of recently, it has become possible to calculate the principal tectonic stress directions from an analysis of the orientations of the joints in a region (Kohlbeck and Scheidegger, 1977). This note is intended to make a comparison between the "seismic stress directions" and the "tectonic stress directions inferred from joints" in the Alps. It will be shown that the two methods agree with each other quite well for the territories of Switzerland.

2. SWITZERLAND AND ADJACENT TERRITORIES.

a) Fault plane solutions.

Fault plane solutions of Swiss earthquakes have recently been collected by Pavoni (1977). His list contains 15 earthquakes (referenced in Table 1 as "PAVO 1-15»). The original references to these earthquakes may be found in the cited article of Pavoni (1977).

Additional earthquakes in Switzerland had been analyzed by the writer (Scheidegger, 1967). Amongst these, there was the main shock at Sarnen of 14 th March 1964 which was re-evaluated by Pavoni. In the Table, this earthquake is given in Pavoni's evaluation; the others are given as listed in the cited paper of the writer's (referenced as AES $-10,-13)$.

b) Joints.

Regarding joints in Switzerland, we refer to an investigation of the writer's (Scheidegger, 1977 a) in which measurements at 14 "locations " have been reported. The determination of the "preferred" joint orientations (according to the statistical method of Kohlbeck and Scheidegger, 1977) together with the determination of the corresponding $P$ and $T$-axes for these locations is given in Table 2. The joint-pole density diagram for this procedure is shown in Fig. 1.

c) Comparison.

It is now possible to make a comparison between the principal stress directions inferred from fault plane solutions and those inferred from joint-orientation data. 
TABLE 1

Earthquake fault plane solutions in Switzerland and adjeacent territories

\begin{tabular}{rllllll}
\hline \multicolumn{1}{r}{ Ref. } & Date & \multicolumn{2}{c}{ Epicentre } & $P$ & $T$ & Region \\
\hline PAVO - 1 & $61-04-28$ & $47.7 \mathrm{~N}$ & $7.9 \mathrm{E}$ & $134 / 18$ & $38 / 18$ & Schopfheim \\
2 & $64-03-14$ & $46.9 \mathrm{~N}$ & $8.3 \mathrm{E}$ & $139 / 11$ & $37 / 44$ & Sarnen \\
3 & $68-02-05$ & $46.6 \mathrm{~N}$ & $5.8 \mathrm{E}$ & $137 / 7$ & $314 / 84$ & Clairvaux \\
4 & $71-06-21$ & $46.4 \mathrm{~N}$ & $5.8 \mathrm{E}$ & $315 / 32$ & $54 / 14$ & Jeurre \\
5 & $71-09-29$ & $47.1 \mathrm{~N}$ & $9.0 \mathrm{E}$ & $158 / 0$ & $68 / 6$ & Glarus \\
6 & $73-05-08$ & $45.6 \mathrm{~N}$ & $9.7 \mathrm{E}$ & $297 / 22$ & $43 / 35$ & Bergamo \\
7 & $73-07-09$ & $46.8 \mathrm{~N}$ & $9.7 \mathrm{E}$ & $156 / 3$ & $66 / 3$ & Arosa \\
8 & $74-01-19$ & $47.7 \mathrm{~N}$ & $7.5 \mathrm{E}$ & $124 / 5$ & $214 / 5$ & Berner Alpen \\
9 & $74-04-26$ & $47.2 \mathrm{~N}$ & $7.9 \mathrm{E}$ & $354 / 18$ & $240 / 51$ & Berner Mittellano \\
10 & $75-05-21$ & $45.8 \mathrm{~N}$ & $8.9 \mathrm{E}$ & $351 / 4$ & $82 / 19$ & Varese \\
11 & $75-12-29$ & $47.1 \mathrm{~N}$ & $9.2 \mathrm{E}$ & $311 / 14$ & $41 / 1$ & Glarus \\
12 & $76-01-29$ & $46.3 \mathrm{~N}$ & $7.5 \mathrm{E}$ & $111 / 58$ & $8 / 10$ & Valais \\
13 & $76-03-02$ & $47.6 \mathrm{~N}$ & $9.4 \mathrm{E}$ & $346 / 0$ & $76 / 0$ & Bodensee I \\
14 & $76-03-22$ & $47.0 \mathrm{~N}$ & $7.0 \mathrm{E}$ & $148 / 0$ & $58 / 0$ & St. Blaise \\
15 & $76-03-26$ & $47.6 \mathrm{~N}$ & $9.5 \mathrm{E}$ & $348 / 0$ & $78 / 0$ & Bodensee II \\
\hline 13 & $64-02-17$ & $46.95 \mathrm{~N}$ & $8.22 \mathrm{E}$ & $275 / 0$ & $5 / 0$ & Sarnen-Vorbeben \\
\hline 10 & $64-05-28$ & $46.8 \mathrm{~N}$ & $9.05 \mathrm{E}$ & $86 / 0$ & $356 / 0$ & Graubünden \\
\hline
\end{tabular}


For this purpose, the $P$ - and $T$-axes found from focal mechanisms are averaged by means of the method developed for this purpose. The results obtained in this fashion are shown in Table 2. The corresponding density diagrams for the axes on the focal sphere are shown in Fig. 2

TABLE 2

\begin{tabular}{lcc}
\hline \multicolumn{3}{r}{ Principal stress axes in Switzerland } \\
\hline & $P$ & $T$ \\
Earthquakes & $322 / 1$ & $43 / 13$ \\
Joints & $119 / 2$ & $210 / 3$ \\
\hline
\end{tabular}

and 3. Similarly, the preferred joint-orientations for all of Switzerland are calculated by using the preferred joint-orientations at each location as input into the standard joint-evaluation procedure of Kohlbeck and Scheidegger (1977).

Because of the manner in which the mean axes were calculated for earthquakes, it is clear that these axes will not generally be orthogonal. Thus, the mean result for the earthquakes does not

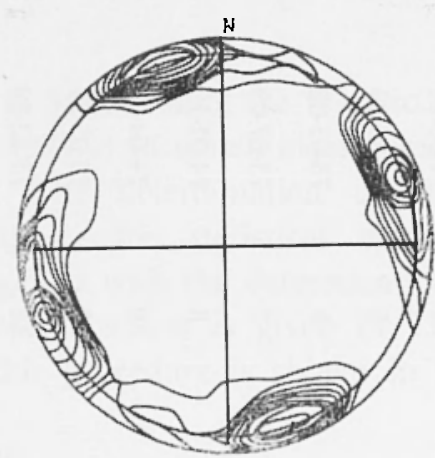

Fig. 1. Joint-pole density diagram for Switzerland. Lambert projection of the lower half of the fundamental sphere; inner circle is the fundamental circle; outer circle corresponds to $-10^{0}$ dip. Density lines correspond to $1,2,3, \ldots$ etc. per cent. 
actually represent a best-fitting mean seismic stress state, but simply the best fitting values for the $P$-and $T$-axes separately. In this, it is seen that the $T$ (least compression axes) as calculated from earthquakes and joints agree with regard to trend within $13^{\circ}$, the $P$ (maximum compression axes) within $23^{\circ}$. This, considering the errors of the various procedures, must be regarded as a good agreement.

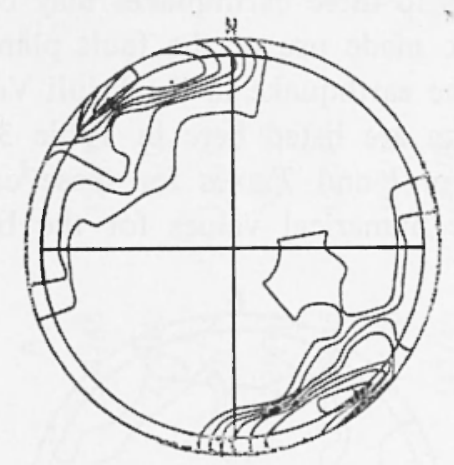

Fig. 2. Density-diagram for $P$-axes from earthquakes in Switzerland and vicinity. Geometry as in Fig. 1.

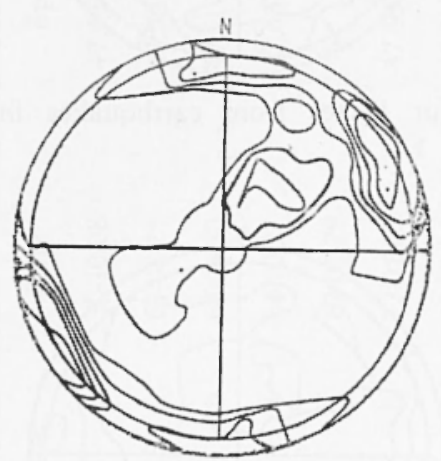

Fig. 3. Density-diagram for $T$-axes from earthquakes for Switzerland and vicinity. Geometry as in Fig. 1. 


\section{AUSTRIA AND ADJACENT TERRITORIES.}

Any attempt to compare seismic and geological stresses in Austria and adjacent territories suffers from the paucity of earthquake fault plane solutions in that area. The fault plane solutions of Austrian earthquakes have recently been summarized by Gutdeutsch and Aric (1976). The original references to these earthquakes may be found in the cited paper. In addition, we made use of the fault plane solution published by Müller (1977) of the earthquake in the Friuli Valley of 6 May 1976. The thus collected data are listed here in Table 3.

The distribution of $P$-and $T$-axes for these earthquakes is shown in Fig. 4 and 5 The numerical values for the best-fitting means are

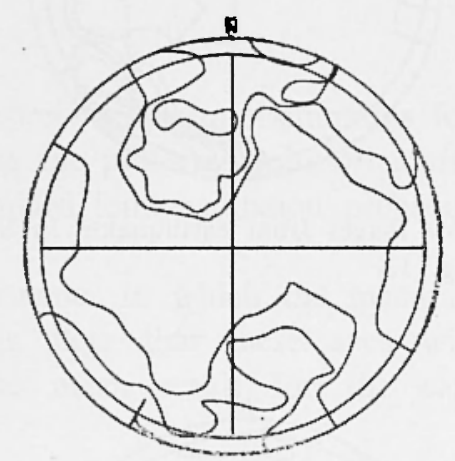

Fig. 4. Density-diagram for $P$ axes from earthquakes in Austria and vicinity. Geometry as in Fig. 1.

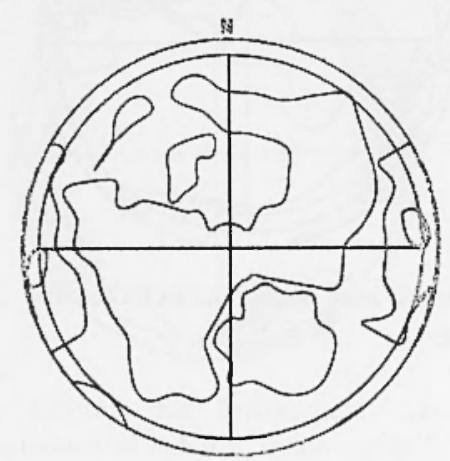

Fig. 5. Density-diagram for $T$-axes from earthquakes in Austria and vicinity. Geometry as in Fig. 1. 
TABLE 3

Earthquake fault plane solutions in Austria and adjacent territories

\begin{tabular}{|c|c|c|c|c|c|c|c|}
\hline \multicolumn{2}{|c|}{ Ref. } & \multirow{2}{*}{$\begin{array}{c}\text { Date } \\
30-10-08\end{array}$} & \multicolumn{2}{|c|}{ Epicentre } & \multirow{2}{*}{$\begin{array}{c}P \\
331 / 45\end{array}$} & \multirow{2}{*}{$\begin{array}{c}T \\
151 / 45\end{array}$} & \multirow{2}{*}{$\begin{array}{l}\text { Region } \\
\text { Tirol }\end{array}$} \\
\hline $\mathrm{G}-$ & 2 & & $47.45 \mathrm{~N}$ & $10.78 \mathrm{E}$ & & & \\
\hline AES & 2 & $61-08-25$ & $47.50 \mathrm{~N}$ & $10.50 \mathrm{E}$ & $279 / 00$ & $11 / 00$ & Allgäu \\
\hline $\mathrm{G}$ & 5 & $64-06-30$ & $47.60 \mathrm{~N}$ & $15.80 \mathrm{E}$ & $45 / 11$ & $136 / 02$ & Semmering \\
\hline $\mathrm{G}$ & 4 & $64-10-27$ & $47.60 \mathrm{~N}$ & $15.80 \mathrm{E}$ & $228 / 06$ & $323 / 35$ & Semmering \\
\hline G & 3 & $67-01-29$ & & & $339 / 45$ & $159 / 45$ & Molln \\
\hline G & 6 & $72-01-05$ & $47.60 \mathrm{~N}$ & $16.25 \mathrm{E}$ & $191 / 00$ & $101 / 15$ & Wr. Neustadt \\
\hline G & $7 \mathrm{~A}$ & $72-04-16 / 1$ & $47.70 \mathrm{~N}$ & $16.15 \mathrm{E}$ & $147 / 40$ & $244 / 08$ & Seebenstein \\
\hline G & $7 \mathrm{~B}$ & $72-04-16 / 2$ & $47.71 \mathrm{~N}$ & $16.06 \mathrm{E}$ & $353 / 14$ & $82 / 00$ & Neunkirchen \\
\hline M & & $76-05-06$ & $46.31 \mathrm{~N}$ & $13.31 \mathrm{E}$ & $163 / 29$ & $00 / 58$ & Friaul \\
\hline
\end{tabular}


given in Table 4. Again, as with the Swiss data, the thus calculated axes do not form an orthogonal system; i. e. they do not represent the best-fitting seismic «stress system », but only the best fitting seismic $P$-and $T$-axes individually.

TABLE 4

Principal stress axes in Austria and vicinity

\begin{tabular}{lll}
\hline & \multicolumn{1}{c}{$T$} & \multicolumn{1}{c}{$P$} \\
\hline Earthquakes & $1 \pm 47 / 7 \pm 40$ & $127+75 / 10 \pm 40$ \\
Joints & $504 / 2$ & $54 / 3$ \\
\hline
\end{tabular}

TABLE 5

Preferred joint orientations in Austria and vicinity (dip direction $N \rightarrow E$ and dip)

\begin{tabular}{lrr}
\hline \multicolumn{1}{c}{ Region } & Max. & Max. 2 \\
\hline D-Altenburg & $14 / 84$ & $273 / 86$ \\
Wiencrwald & $19 / 86$ & $107 / 84$ \\
Pauliberg & $184 / 89$ & $92 / 90$ \\
Lcithagebirgc & $42 / 89$ & $137 / 89$ \\
Gleinalmtunnel & $204 / 74$ & $100 / 75$ \\
Stubalpc & $344 / 85$ & $81 / 89$ \\
Ebriachklamm & $169 / 70$ & $255 / 78$ \\
Wörschach & $66 / 87$ & $166 / 90$ \\
Hallstatt & $290 / 81$ & \\
Hochkönig & $62 / 90$ & $146 / 87$ \\
Irschen & $52 / 84$ & $334 / 89$ \\
Kals & $248 / 90$ & $157 / 88$ \\
Fclbertal & $213 / 85$ & $116 / 88$ \\
Allgau & $242 / 67$ & $128 / 75$ \\
\hline
\end{tabular}

Next, we have to calculate a mean value for the stress axes from data on joint orientations. For this purpose, we have taken the data for various Austrian and adjacent regions published previously (Scheidegger, 
1974; Carniel et al., 1975; Hauswirth and Scheidegger, 1976; Scheidegger, 1977 b).

To these, we have added some new data from the Allgäu provided by Dr. Haussler of the Bayerische Geologische Landesamt. The regions and the best fitting joint orientations for them (dip direction $N \rightarrow E$ and dip) are given in Table 5 . Then, the $P$-and $T$-directions for the combination of these regions have again been calculated by the method of Kohlbeck and Scheidegger (1977). The numerical data are given in Table 4, the corresponding po'e-density diagram is given in Fig. 6.

In view of the large scatter of the data, the above results, however, have no real significance.

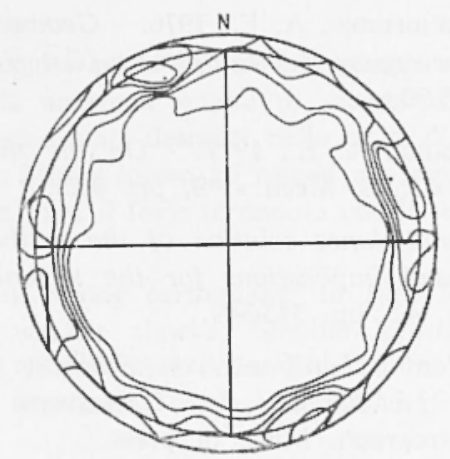

Fig. 6. Joint-polc density diagram for Austria and vicinity. Geometry as in Fig. 1.

ACKNOWLEDGEMENTS.

The author is grateful to Dr. H. Häussler of the Bayerisches Geologisches Landesamt for the supply of 1318 joint measurements form the Sonthofen (Allgäu) region. Furthermore, Dr. N. Pavoni of the Federal Institute of Technology in Zürich sent to the author a copy of his paper on Swiss fault plane solutions prior to publication.

The calculations and plots were made at the Computing Center of the Technical University of Vienna which is here gratefully acknowledged. 


\section{REFERENCES}

Carniel, P., Hauswirth, E. K., Roch, K. H., Scheidegger, A. E., 1975. - Geomechanische Untersuchungen in einem Rutschungsgebiet im Felbertal in

Österreich. «Verh. Geol. B. - A. », Jg. 1975, 4, pp. 305-330.

FARA, H. D., Scrheidegger, A. E., 196. - An eigenvalue method for the statistical evaluation of fault plane solutions of earthquakes. "Bull. Seismol. Soc. Am. ", 53, pp. 811-816.

Gutdeutsch, R., Aric, K., 1976. - Erdbeben im ostalpinen Raum. Publ. Zentralanstalt Met. u. Geodyn. Wien, 210, pp. 1-23.

Hauswirth, E. K., Scheidegger, A. E., 1976. - Geomechanische Untersuchungen der Grosshangbewegung Hallstatt-Plassen (Österreich). "Riv. Ital. Geofis », III $1 / 2$, pp. 85-90.

Kohlbeck, F., Scheidegger, A. E., 1977. - On the theory of joint orientation measurements. "Rock Mech.", 9, pp. 9-25.

MüLLER, G.. 1977. - Fault-planee solution of the earthquake in Northern Italy, 6 May 1976, and implications for the tectonics of the Eastern Alps. «). Geophys. », 42, pp. 343-349.

Pavoni, N., 1977. - Herdmechanismen von Erdbeben und regionalteklonisches Spannungsfeld in Bereich der Geotraverse Basel-Chiasso. Schweiz. Mineral. u. Petrograph. Mitt., in press.

Scheidegger, A. E., 1967. - The tectonic stress in the vicinity of the Alps. «Z. Geophys ". 33, pp. 167-181.

ScHEIDEgGER, A. E., 1974. - The acient and contemporary geophysical stress field in a calcareous mountain-range. "Annali di Geofisica», XXXVII, 1/2, pp. 333-348.

SCHEIDEgGER, A. E., 1977 a. - Klufimessungen im Gelände und ihre Bedeutung für die Bestimmung des tektonischen Spannungsfelds in der Schweiz. "Geographica Helvetica », 32 (1).

Scheidegger, A. E., 1977 b. - Geotectonic stress-determinations in Austria. Trans. Internat. Sympos. Field Measurements in Roch Mech., Zürich (in press). 